\title{
Editorial
}

\section{Legal Services and Advocacy in the Industrial Revolution 4.0: Challenges and Problems in Indonesia}

\author{
Ridwan Arifin \\ Faculty of Law, Universitas Negeri Semarang, Indonesia \\ Editor in Chief, Indonesian Journal of Advocacy and Legal Services \\ $\searrow$ ijals@mail.unnes.ac.id, ridwan.arifin@mail.unnes.ac.id
}

THE INDUSTRIAL revolution 4.0 had a significant influence in various sectors, including the law enforcement sector. Law enforcement, legal aid, legal services and advocacy in the industrial revolution 4.0 era have their own characteristics of challenges. This edition of the Indonesian Journal of Advocacy and Legal Services raises the theme of Legal Services and Advocacy in the Industrial Revolution 4.0 in the hope of providing a new picture, discourse, and treasury in the provision of services and legal assistance, advocacy and community assistance.

At the foundation of Industrial Revolution 4.0 tiself are the themes of "data" and "connectivity." To dispel a myth, Industrial Revolution 4.0 is not technology in and of itself, but rather, a concept of how automation can be better utilized to help companies achieve operational goals that are aligned with business strategies. The Industrial Revolution 4.0 discussion within an enterprise should begin with the business strategy. Where is the company headed? Is top-line growth the priority, and is increased capacity to meet demand the focus for operations? Is the business focused on reducing costs to remain competitive in a market with tightening margins? and what about manufacturing flexibility? How is the company addressing new market pressures, such as the ability to meet customization demands? 1

In the other context, Fonseca emphasized that industry 4.0 is quite recent and there is still no consensus on this concept, as some authors might call it Advanced Manufacturing, Smart Manufacturing, Smart Factory,

Ron Stuver, Why should I care about Industry 4.0?, Smart Industry Forum, 1 November 2019, https://www.smartindustry.com/blog/smart-industry-connect/why-should-i-careabout-industry-4-0/ 
Internet of Things, Internet of Everything, or Industrial Internet, to express the same concept. However, based on the literature review, we summarize that the "4th Industrial Revolution" is characterized by the advanced digitalization and integration of industrial manufacturing and logistics processes, and the use of internet and "smart" objects (machines and products). The adoption of information and communications technology (ICT) is merging the physical and virtual worlds, in what is called the cyberphysical production systems (CPPSs) that consist of online networks of social machines, linking IT with mechanical and electronic components, that communicate between themselves via a network. Industry 4.0 creates higher value-added chains and changes the classical human and production organization systems, and the organizational business models, impacting the overall society and the environment. ${ }^{2}$

Moreover, Sangokoya highlighted that Industrial Revolution introduces particularly new challenges relative to past revolutions-signs of which we are already seeing today, such as Persistent risks to digital rights through the sheer interconnectedness of new technologies, High-powered propaganda tools in the attention economy, Navigating the relationship with new digital social movements, Threats to transparency and accountability, and New context for questions on the ethics of innovations that take us beyond the level of humanity. ${ }^{3}$

Journal of Advocacy and Legal Services, at this edition, provides some articles related to the Industrial Revolution 4.0, for example, how to prevent drugs abuse in this disclosoure era, Ramadhan et.al highlight the need for education and understanding provided to the community, especially in the Tegalrejo sub-district region, is expected to reduce the number of drug users. The educational activities carried out received enthusiasm from the residents of Tegalrejo, which was attended by many residents from various backgrounds, starting from community leaders, village officials and attended by local youth or youth.

Another article, Advanced Training of Intellectual Property Documents of Industrial Designs for Goyor Sarong Craftsman in Pemalang District, written by Waspiah et.al concluded that the participants of the activity paid considerable attention to the Training of Proficiency in Intellectual Property Document Development Industrial Design in the

2 Luis Miguel Fonseca, Industry 4.0 and the digital society: concepts, dimensions and envisioned benefits, Proceedings of the 12th International Conference on Business Excellence2018, pp. 386-397, DOI: 10.2478/picbe-2018-0034

3 David Sangokoya, 5 challenges for civil society in the Fourth Industrial Revolution, World Economic Forum, 18 December 2017, https://www.weforum.org/agenda/2017/12/5challenges-facing-civil-society-in-the-fourth-industrial-revolution/ 
Craftsmen of Pemalang Typical Goyor Crafts in the District Pemalang. This can be seen from the enthusiastic craftsmen and designers during the training. During the training there were many questions about knowledge about Intellectual Property not only industrial design but also other intellectual property regimes such as brands and copyrights. In particular, industrial designs, craftsmen and new designers know that what they design has legal protection to avoid the use of irresponsible parties.

Nune et al, Code of Ethics and the Role of Advocates in Providing Legal Aid to the Poor, dicuss and analyse Law No. 18 of 2003 concerning Advocates emphasizes the status of Advocates as one of the law enforcers who have roles and functions that are equal to the Police, Prosecutor's Office and Judicial Power as law enforcement officers, but there is specialness given by the law to lawyers, namely the independence of advocates in carrying out their duties and profession. The independence of advocates aims to support the implementation of a justice system that is free from power and political intervention in law enforcement, and with that independence the Advocate Profession is said to be a very noble profession (offiicium nobile). As a noble profession, of course, advocates are bound by ethical values that become the guidelines in the implementation of their duties and authorities, where those values are posited as a Professional Code of Ethics.

Finally, I have to express my great thankfulness to all Authors and Contributors, Reviewers, as well as Editorial team of this Journal edition for their invaluable supports, inputs, suggestions, and comments. I also would like to thank to my students, Ririn Rahmawati and Zulva Hayati, who Reviewed two releted Books. 


\title{
The Industrial Revolution was another of those extraordinary jumps forward in the story of civilization.
}

\author{
Stephen Gardiner
}

Copyrights (C) 2020 by Auhtor(s). This work is licensed under a Creative Commons Attribution-NonCommercial-ShareAlike 4.0 International License. All writings published in this journal are personal views of the authors and do not represent the views of this journal and the author's affiliated institutions. 